\title{
KEMALISM, HYPER-NATIONALISM AND ISLAM IN TURKEY
}

\author{
Ümit Cizre-SakallioḠLU*
}

The rising and falling political fortunes of Islam and hyper-nationalism ${ }^{1}$ in Turkey over the long period of their evolution can best be understood in relation to the ebb and flow of Kemalism, the official ideology of the republic, named after its founder, Mustafa Kemal Atatürk. Kemalism was the secular, positivistic and rational ideology of the republic determined to build a nation-state out of the multi-national Ottoman Empire, and then to modernise it on Western lines. In general, as bases of state formation and legitimation, Islam and the radical variant of pan-Turkish nationalism have had an antagonistic relationship with Kemalism throughout the life of the republic.

Both Islam and, to some extent, radical nationalism have challenged Kemalism on the very grounds of its raison d'être. Both ideologies have claimed superiority in providing better sources of national identity, social cohesion, political unity and government tradition than Kemalism. Whereas Kemalist nationalism committed itself to a feverish programme of Westernisation, the overriding tenet of radical nationalist and Islamist forces has been a strong rejection of the Western paradigm of modernisation. Instead, both ideologies have advocated a return to traditional values and institutions, one supplanting Westernisation by Turkification, the other by an Islamisation process. The only Western element of the two has been their advocacy of the adoption of Western technology and science; for other reasons, they have also shared in the liberal democracies' anti-communism. Islam and radical nationalism have expended much energy on trying to offer more efficient mechanisms for state-building, and as the political violence instigated by hyper-nationalist forces in the 1970s showed, for state-wrecking.

Radical Islam and radical nationalism also differ sharply from the Kemalist principles of nationalism on two important accounts. The first is related to their conception of democracy and thus of the role of Islam in politics; the other is on the principle of territoriality. On the first account, it is true that the Kemalist state had a tutelary character and took the sole initiative in structuring and organising the state-society relationship including the role of Islam. On the other hand, its repudiation of Islam as the basis of legitimacy of the state, and instead, its adoption of the secular principle of popular sovereignty is a clear sign that the Kemalist regime intended to turn into a parliamentary democracy of the Western type in the long run. By contrast, both radical Islam and radical nationalism are against the Western-based notions of electoral mechanisms and participatory

*Assistant Professor of Political Science, Bilkent University, Ankara, Turkey.

This article was completed in August 1992. Its analysis reflects events as they stood at that time. 
democracy, although from time to time they have had to pay lip service to them. Both ideologies overrely on the state as the originator of all social change, one in the direction of Islam, the other in the authoritarian nationalist ideals of the leader.

Furthermore, the concern of Kemalist nationalism was a territorial one, restricted to creating national consciousness only for the Turks living within the boundaries of the Turkish nation-state. While for the Islamists the focus of identity of the Muslims is supra-national, for the hyper-nationalists it is 'panTurkism' which aims at bringing all the Turks living in the neighbouring countries and in the ancestral lands of Central Asia under the leadership of the Turkish state. Another more ambitious ideal of the hyper-nationalists is 'Turanism' which means uniting all the Turkic origin groups scattered around the world. It is true that at the initial stages of nation-building, Kemalism assigned some role to ethnicity as a central component of nationalism. This phase passed and hyper-nationalists gradually began to oppose Kemalist nationalists by the end of the Second World War.

Relations between ethnic nationalism and religion itself in Turkey have been as complex and curvilinear as in the other countries in the Middle East. ${ }^{2}$ Similarly, the value and norm structures they have maintained among their adherents have sometimes been 'reinforcing', at other times 'conflicting', ${ }^{3}$ considering the fact that religion has provided the indispensable ingredient of national identity both in Turkey and in the region.

Following the inception of the Republic in 1923, the early years furnish us with the example of secular ethnic nationalism replacing Islam as the source of state legitimacy, while in the $1970 \mathrm{~s}$ and the $1980 \mathrm{~s}$, ethnic hyper-nationalism has incorporated more and more Islamic themes into its discourse. Moreover, the radical Islam of the $1980 \mathrm{~s}$ was involved in a struggle to dismantle the secular basis of the Kemalist nation-state and restructure it on the basis of Islamic maxims. In what follows, an attempt will be made to trace the structural and dynamic properties of the relationship between Kemalism, the still-official ideology of the state, and its mostly opposing but sometimes collaborating rivals of Islam and hyper-nationalism.

\section{KEMALISM AND ISLAM}

In Turkey in the 1990s, it seems beyond doubt that the principal political challenge to the still-secular state comes from political Islamists. In a country where Islam has always been part of the national 'identity', but not necessarily practised as a militant instrument of political opposition, the secularist camp is alarmed by the increasing manifcstations of Islam as a radical rcligio-political movement. To understand fully the relationship between Kemalism and Islam, it is imperative to begin with the present, and then go back to the past.

The present strength of radical Islam can be seen in its major impact on the social and political life of Turkey in the last decade: to begin with, religious instruction in primary and secondary schools became an article of the new constitution of 1982, allegedly to pre-empt the Islamic indoctrination under way in countless private institutions run by Islamists. In addition, the activities of 
Islamic orders, ${ }^{4}$ which had been banned in the early republic in 1925 , have reached unprecedented levels, Süleymanci and Nakşibendi orders run unofficial Qur'ān courses and youth hostels for needy youngsters who have come from provincial and rural areas to be educated in the big cities. Orders penetrate the ranks of government, business and society in general, with their ardent proponents of at least a semi-Islamic state. In its own publications, each religious group or order disseminates its specific views on and methods of returning to shari' $a$, the organising principle of social, economic and political life based on the Qur'an. The numbers and the circulation of these publications have mushroomed in the last decade.

Some orders have found followers even among the military cadets of the military schools, bastions of Kemalist secularism, and have turned the universities, hotbeds of socialist movements in the 1960s and 1970s, into testing grounds for the religious headscarf to be worn by Islamist female students. One prime example of their appeal and influence among Turkey's political leaders came in May 1989, when the mother of then-prime minister Turgut Özal was buried next to one of the most important sheikh-leaders of the Nakşibendi religious order, Mehmet Zahit Kotku, in the graveyard of Istanbul's Süleymaniye Mosque. The burial required a special decree of the cabinet and ratification by then-president ex-general Kenan Evren.

In the last decade, apart from the activities of the religious orders, there have been other manifestations of fundamentalism which are extremely disturbing and unsettling for secularists from all walks of life. In recent years, eminent professors, intellectuals and journalists still promoting the concept of a secular state were assassinated by uncaught killers thought to be members of radical Muslim organisations. The concern of secularist public opinion is doubled when it sees radical Islamist ideology permeating all levels of society: from the banking system, universities and public figures, to the police, intelligentsia, liberal professions and the media.

It is the contention of this article that what Turkey has been facing in the 1980 s and 1990s is a novel and original challenge of Islam to Kemalism rather than another instance of its historic endurance, as seen in the 1950s and 1970s. Above all, today's challenge is the product of a deep-seated malaise which in itself is not explicable in purely religious terms alone, but in political, social and cultural variables extending over the whole republican era. A two-level analysis of present and past factors should be made. Since the early republic set in motion by its Kemalist foundation the firm oppositional character of Islam to the secular Turkish state, on the first level, historical analysis must survey the development of the relationship between secularism and Islam throughout the mono(1923-1946) and multi-party (1946 onwards) periods. This historical perspective should also examine both 'state' and 'society' as two interrelated variables triggering responses to each other.

Post-1980 Islamist forces, however, are not only products of the accumulated wisdom of the past, but also of the creation of the post-1980 state and its selfperceived constraints. On the second level, therefore, this analysis will focus on the more immediate context of the 1980s, its changing balance of political forces and ideologies, and the arterial sclerosis of Kemalism which became manifest in the last two decades. 


\section{Kemalist secularism and the pre-1980 Islamist challenge}

Following the fall of the Ottoman Empire (1299-1918), precipitated by the defeat of the Central Powers and the November 1918 armistice, nationalist forces under the leadership of Mustafa Kemal launched a successful war of liberation against the colonialist Western powers, to preserve the integrity of the remaining Turkish region, the Anatolian Peninsula, as the basis of the new republic eventually proclaimed in 1923. During these early formative years of the republic, the six fundamental political principles of what came to be known as Kemalism were laid down. They were reformism, republicanism, secularism, popularism, etatism and nationalism. The objectives of this ideology and the ruling Republican People's Party (RPP) were twofold: to firmly establish a Turkish nation-state, and to ensure its Westernist and modernising character unhindered by a state doctrine of any religion. In other words, religion was thought to be detrimental to the initial survival and then to the 'progress' of the Turkish nation-state because of the ideas, values, outlook and attitudes it bred both at the individual and systemic levels. For that reason, the eradication of the influence of religion from both personal and public levels became the utmost concern of Kemalist cadres, and thereby gave impetus to the eventual religious reaction.

From 1922 to 1924, the sultanate, the caliphate, the Office of Şeyh'ül-Islam, the highest religious authority in the Ottoman Empire, and the Sharia courts were all abolished. Between 1925 and 1930, religious orders and Ottoman-Muslim headgear for men, the fez, were outlawed. Swiss civil and Italian penal codes and the Latin alphabet were adopted. In 1928, the second article of the 1924 constitution which stated that Islam was the state religion was annulled and the principle of secularism was inserted into the constitution in 1937. The secularisation reform package was intended to serve three functions; the first was 'cultural Westernisation'. Combined with the positivist-empiricist sciencebased thinking of Kemalist cadres-who were, after all, themselves products of the secular educational reforms of the Ottoman Empire-these reforms laid the cultural preconditions for modernisation of Turkish society on Western lines. This was a radical commitment, and there could be no compromise with religion.

Secondly, and in political terms, these reforms were an attempt to shift the basis of political legitimacy from Islam to the French Revolution's secular democratic principle of popular sovereignty. Secularisation in Turkey was part of the struggle against the 'ancien regime', the Ottoman ruling class. In this sense, it was and has been a precious formula for democratisation, that made possible the transition from an authoritarian mono-party to a more democratic, competitive party system. The extension of political participation to those on the periphery through the formula of universal suffrage, however, had a problematic feature: it would bring the periphery, with its religious orientation and traditionbound outlook, into a political system based on the negation of Islam. This contradiction in terms was fortunately but only temporarily resolved by monoparty authoritarian etatism and its concept of populism which denied the existence of social classes. Since the economic model adopted was state capitalism, the strong, centralised bureaucratic apparatus was able to control and structure the emerging capitalist and working classes and coopt them into the system. 
Thirdly and finally, the reform packet aimed at liberating the individual from the 'oppressive' constraints of Islam-as-culture in his own community, ${ }^{6}$ and creating 'a new man'. One can easily detect here the fear of folk Islam, organised around a multiplicity of orders, sheikhs, sects, cults and practices, posing both a political and a cultural threat to the Republic. The government adopted a double strategy: on the one hand, Islam was put under central control by creating within the state apparatus a Directorate of Religious Affairs to regulate the religious activities of the public; on the other hand, through a more time-consuming and much more difficult route, modern secular values were inculcated into society through education and socialisation. It was hoped that over time the regressive, behind-the-scenes role of religion on the level of the individual would thus be curtailed.

In its drive for secularisation, the Kemalist elite was also motivated by other concerns: in a country which was divided basically into two sects-the majority Sunnis and the minority Alevis (historically linked to but completely different from the Shiites in Iran)-the Kemalist secularisation process strove to foreclose the possibility of future sectarian strife coinciding with ethnic divisions between Turks and Kurds. The 1970s demonstrated the far-sightedness of that concern.

Establishment of secularism as the pillar of the republic produced deeplyrooted tensions between the regime and the Islamic religion, and thus set the tone of religious dissidence for years to come. For one thing, moral outrage in the countryside at the Westernisation project produced conditions conducive to anti-secular movements. Kemalism has been criticised on this point, for failing to understand the role religion played for the individual, ${ }^{7}$ providing the basic ingredients of his communal self-identity and emotional security. His perceptions of the social and political system and of his role in that system were guided and conditioned by the religion he was born into, and he was not to be cut off easily from this source. The actual or spill-over effects of socio-economic modernisation were not speedy enough to produce the expected transformation of the cultural outlook of the individual, either. 'In this sense, 'fundamentalism' and 'revivalism'-though admittedly subterranean for years-have had a much longer history than one usually realizes'. ${ }^{8}$

However, in the Republic's first two decades, the politico-religious opposition on the periphery had neither the vision nor the means to organise an effective assault against the earthly phenomenon of Kemalism. Despite the problems of the long-term institutionalisation of secularism, the record of success of the mono-party years was impressive: 'Turkey in the 1930 s, ... appeared an avowedly secular society'. ${ }^{9}$ Indeed, the activism, the vitality of its programme, and the democratic intentions of the Kemalist regime appear to have been responsible for the great following it secured among the urban intelligentsia.

The peaceful manner in which the state party, the RPP, acquiesced in transferring political power to an obscure new party, the Democrat Party (DP), in the 1950 elections can probably best be explained by the RPP's sincere commitment to political democracy of the Western type. The new democratic orientation of the post-war period in the West also facilitated the introduction of competitive party politics in Turkey. The DP won the next two elections of 1954 and 1957 and stayed in power until overthrown by the military coup of 1960 .

The DP's attitude toward religion was solely shaped by pragmatic 
considerations of reaching out to a new political constituency on the periphery, the rural voters. It is not surprising that the DP, lacking a previously-cultivated power base both at the grass roots of society and in the bureaucracy by patron-client networks, discovered religion and identified itself with the cause of peripheral Islam. To put it differently, the DP's courting of religion as electoral tactics was the product of the dismal failure of Kemalism to institutionalise the politics of secular opposition. Turkey in the 1950 s was a polity with no known routes of political participation and mobilisation other than general elections, with no associational life, and with '... a low institutional penetration of society by the state'. ${ }^{10}$ If the result of this can be interpreted as '.. a victory of the periphery over the center ...', ${ }^{\prime \prime}$ then it seems ironic that peripheral Islam had also discovered the secular political process.

The first coup in the Turkish Republic, in 1960, represented a watershed in the Turkish political landscape, particularly for the role of Islam. The new constitution of 1961 was a monument in its reaction to the authoritarian policies of the DP, incorporating measures of liberal democracy and political pluralism. Basic rights and liberties were introduced; associational freedoms were established; a process to resolve conflicts and struggles in the political arena was institutionalised. It was in this last respect that the power of the Kemalist bureaucracy vis-à-vis civil society could still be maintained, and the Kemalist version of secularism could still be safeguarded. Although religious freedom in the form of freedom of conscience and prayer was introduced, basing the state on Islamic rules was still outlawed, and as a result, any attempt to change the secular character of the state remained a criminal offense. It can be argued that objective conditions were the impetus for this political liberalisation and democratisation: Turkey's pre- 1960 political system had grown too antiquated to meet the needs of a polity becoming more complex and socially differentiated.

The first pro-Islamic political party in the republic came into existence in 1969, in the more permissive climate of the 1960s, under the name of the National Order Party. After the military intervention of 1971, it was dissolved, soon to be replaced in 1972 by a successor party, the National Salvation Party (NSP), whose life-span extended until its abolition by the military in 1981. The party became a key partner in three coalitions between 1974 and 1977, and was the third largest party in the political system in terms of the seats it occupied in the National Assembly, even though both the percentage of its votes and the seats it had were reduced in the 1977 elections.

The political impact of the NSP cannot be measured solely by the criterion of electoral returns. The party represented a breakthrough of religion into the political arena as it started to utilise the country's major political platforms, actors and forms for its own causes rather than vice versa. The originality of the NSP therefore, lay most of all in its organisational novclty. It was a brand new form of Islamic expression, a modern political party, a radical departure from the forms of political agitation and opposition used by the heterodox peripheral Islam of the sheikhs, brotherhoods, spirits, and lodges.

The NSP made its unique contribution to the evolution of modern political Islam in basing its strategy not on short-term electoral gains but on the long-term goal of promoting the role and importance of Islam in Turkish politics. It assumed that the precondition for the realisation of this objective was to wage the 
struggle against the secular state on the proper political level, with a proper political form, and from a legitimate place. This, the NSP achieved beyond any doubt. The NSP also played a significant role in fostering the right social and psychological climate for unofficial Islam in terms of Qur'ān courses, publication of journals, and religious local associations, thus broadening the base and scope of the Islamist movement. Building an organisational network, the NSP also brought its Islamist appeal into the workplace, through a labor union (Hak-İş); to young people, through its youth organisation (Akıncılar); and into the universe of professional groups via the party itself. ${ }^{12}$ In addition, the party developed a close relationship with the Nakşibendi order. All in all, without the NSP, post- 1980 religious radicalism would probably still have made inroads, but it could not have got the support of the top political figure, Turgut Özal, and his ruling party. Özal himself had contested the 1977 elections on the NSP ticket, and lost.

\section{The post-1980s: the modernisation of Islam or Islamisation of modernity?}

Why is the Islam of the 1980s and the 1990s feared so much by secular-left and secular-right forces? The primary characteristic of Turkish radical Islam is one which distinguishes it from earlier movements and yet represents an historical continuity with the NSP. In the words of Bruce Lawrence, who speaks of Islamic fundamentalism in general, but whose diagnosis fits the Turkish case, fundamentalists, '. .. espouse an ideology but not a theology, and perhaps one of their enduring values is to force others who use a variety of terms in trying to account for the Muslim world to recognize the chasm that separates theology ... and ideology'. ${ }^{13}$ This ideologisation has made Turkish radical Islam extremely political. Proponents of radical Islam claim that it is a political alternative to Kemalism, socialism and capitalism. Thus, the Islamic movement of the 1980s as a whole has broken with the historical tradition of siding with the status quo and has come to expound the notion of dismantling and then transforming the state on the basis of its ideology. ${ }^{14}$ Only marginal groups seem to favour a violent method to achieve this end. The majority of Islamists do not opt for a revolution, because they expect to infiltrate and then dismantle the state structure from within.

Another important feature which stems from this ideologisation process is the movement's adoption of a more sophisticated and intellectual discourse for developing new ideas based on the Qur'ân. ${ }^{15}$ It is precisely because the fundamentalists recognise the strength of Westernisation that they attack it with modern means of publication propaganda and the consumer paraphernalia of modern technology. A new, opportunistic symbiosis has been formed between non-Islamic modernism and Islamic orthodoxy. This was the natural outcome of the Islamists' wish to broaden their political constituency to diverse elements in and outside electoral channels. This modernisation of Islam or perhaps, as the fundamentalists themselves would prefer to call it, the Islamisation of modernity, owes much to the efforts of the NSP in the previous period.

The tide of Islamic extremism in Turkey in the post-1980 period cannot be claimed to be a revival or a continuation of the historical grievances of the $1950 \mathrm{~s}$ and 1970s; they did not provide this much momentum for the movement. Nor is it a replica of what is happening elsewhere in the Muslim world. On the contrary, 
the vigor and dynamism of the movement owes as much to the policies of the post-1980 Turkish state as to the seeds sown in the past. Why did this state accord $\therefore$... Islam as a religious and social phenomenon unprecedented recognition since $1980 .{ }^{\prime 16}$ There are some fundamental reasons why the state elites of the 1980 s, both during military (1980-1983) and civilian rule, played the card of Islam.

As the authoritarian reconstruction of state and society openly indicated, the first and foremost problem in the minds of the coup-makers and their civilian successors was rebuilding a tightly-integrated, indivisible (in terms of social class, ethnicity or sect), non-ideological and 'consensual' society, like the Turkey of the 1930s. The past obsessional dedication of the Kemalist cadres and the army to 'national unity' at the cost of political democracy, resurfaced. The military and its civilian allies, regarding themselves as the 'guardians' of the integrity and unity of the nations, concluded from the near civil-war situation on the eve of the 1980 coup that Mustafa Kemal had been right in his rejection of social class, ethnicity, sects and religion in defining nationalism because of their divisive effects. On the other hand, they believed that the failure of Turkish political pluralism was, more than anything else, due to the influence of communist ideology and practice over the preceding two decades. The communist menace was thought to be many times worse than religious obstructionism or reaction. Furthermore, after the 1979 Iranian revolution, religion was politically ascendant everywhere. Under the combined impact of all these considerations, Turkey's rulers adopted a policy of reconciliation, recognition and tolerance toward Islam, which was to act as a unifying bond against communism. Religion was systematically promoted as a bulwark against communism and a substitute for class-based ideologies.

The insertion of Islam into Kemalist discourse was, in part, due to the incapacity and helplessness of Kemalism against the rising tide of religion as an authentic and viable ideology. Faced with this tide, the military rulers tried to pre-empt the radical movement by emphasising their own commitment to religious orthodoxy. They missed the important point that the Islam they were dealing with was neither the folk Islam of the masses nor the officialised controllable Islam of the Directorate of Religious Affairs, nor the Islam of 50 years ago. In this vein, compulsory religious instruction in primary and secondary schools was instituted in the belief that rising fundamentalist influence in Turkey was due to insufficient religious education. This strategy undoubtedly aroused mass support, and also was encouraged by conservative and liberal secular circles. ${ }^{17}$

In the last decade, the political profile of Islam has come to combine both of its historic roles as stabiliser and destabiliser of Turkish society. On the one hand, it claims to be capable of replacing the secular state and of stabilising the polity. The problem, is on the other hand, how it would do so. Despite the conciliatory policies of the state toward it, fundamentalist Islam has almost insurmountable obstacles on its way to seizing state power, given the immense advances made in the life of Turkish society since the inception of the Republic.

If radical Islam owes its present status to the tactical mancuvres of the post1980 state, the same state, at a different historical period and under changed constraints, can do the opposite. As the 1990s unfold, radical Islam's chances of overcoming the arch-determiner role of the state seem to depend on a list of factors getting longer with each passing day. 


\section{KEMALISM AND HYPER-NATIONALISM}

The relationship between Kemalism and hyper-nationalist movements and parties has been quite unlike the one between religion and Kemalism. For a very long time, at least until the 1970s, ethnic nationalism shared many tenets with Kemalism and presented less of a threat to the secular state than did religion. Moreover, hyper-nationalism was confined to a small circle of intellectuals with no claim, unlike Islam, to represent the periphery. Thus, the Kemalist state was able to cope with hyper-nationalist tendencies by coopting them, borrowing aspects from them, or simply suppressing them, with no fear of mass reaction emanating from the grass roots.

Why pan-Turkism initially found favour among Atatürk and the Kemalist elite can only be answered by posing another question. If not Islam, what could serve as a bond for social cohesion? There were two potential candidates: a social class-based ideology of socialism, or hyper-nationalism, which glorified the preOttoman origins and culture of Turks on the Central Asian plateau. Under the influence of the corporatist doctrines of Italian fascism, Kemalist populism denied class conflict and conceived the nation as comprising 'the people', the RPP as the 'people's party'. The aim was to preclude the possibility of class-based politics dividing the nation into competing camps. Thus, by a process of elimination of class and religion, the principal cement of national integration became ethnicity, and Atatürkist nationalism had to put its Turkic component at the forefront.

Despite the affinity between official Kemalist ideology and hyper-nationalism, however, there were important differences between the two. The most radical difference was the essentially democratic nature of Kemalism, which, though often illiberal, was never anti-liberal. In contrast, ultra-nationalists expounded a basically authoritarian political discourse with emphasis on monism. The second major difference was on the issue of Islam. Since pan-Turkist nationalism was non-territorial, Islam turned out to be an important unifying component, alongside race. Kemalist nationalism, however, was confined to the territory of Turkey and repudiated Islam. Atatürk himself was highly critical of panTurkism with an Islamic tinge: 'Ignoring frontiers and uniting all the world's Turks is an unattainable goal. This is a reality established by centuries, and by the people who lived in the course of these centuries, through very painful and very bloody events. History does not bear witness to the success and global implementation of Islamism and Turanism'. ${ }^{18}$

\section{Hyper-nationalism and the Nationalist Action Party}

The genesis of the Nationalist Action Party (NAP) was in the extraconstitutional 1960 military takeover. Some of the future NAP founders were members of a group of officers known as 'the Fourteen', who were catapulted into political power in 1960 as members of the junta. The leader of this panTurkist nucleus was colonel Alpaslan Türkeş, whose imprisonment in the 1944 trials was a sign of growing intolerance of official nationalism toward a radical variant. The Fourteen advocated prolongation of military rule and implementation of cultural and technical reforms to establish a truly radical nationalist state based on authoritarian maxims. However, they were ousted from the junta five 
months after the coup by the majority of moderate Kemalist officers. The intention of the Fourteen was to form a political party to counter the rising Turkish left. Five years after the coup, in 1965, they seized the organisation of a small ultra-conservative party and changed its name to NAP in 1969.

The NAP rejected outright the role assigned to Turkish nationalism by the Kemalist state elite in both the mono- and multi-party years, as a passive background 'motif' to unite the nation and increase the efficiency of the modernisation drive. The NAP embarked on a campaign to politicise and radicalise nationalism against communism, by mounting an attack on Westernisation. On this point of anti-Westernism, the NAP deviated from the Kemalist line. Modernisation, based on a Western model, was regarded as the root of all evil, since it had destroyed the nation's values, culture, morals and ideals and paved the way for another alien ideology, communism, which aimed at dividing and dominating Turkey ${ }^{19}$ True enough, anti-communism was an issue which the NAP shared with Kemalists and the ruling continuum of liberalconservatives, but since its ideology was bound up with its effort to uphold the image of a unique Turkish race, culture and identity, it could be not only against communism, but against Westernisation, too.

Until after the 1980 coup, the most prominent component of the NAP's nationalist discourse was, not unexpectedly, pan-Turkism mixed with Turanist and irredentist elements: 'the specific name for Turkish nationalism is Turkism. Its definition is inseparable from that of Turkish nationalism'. ${ }^{20}$ This Turkist-Turanist ideology, although dominant, was to be diluted under the rising rhetoric of Islam, beginning with the historic Third General Congress of 1969 when well-known Islamists were elected into NAP policy-making posts. At this stage, the primary reason for bringing Islamic overtones into the ideological discourse of the party was the pragmatic one of numerically broadening the support base. The leader, Alpaslan Türkes, expressed this very clearly when he stated that '... the Turkish nation consists of devout Muslims. We want those who serve the nation to heed and pay respect to religion. It is necessary to take this into account in mobilising the energy of the people ${ }^{\prime 2}{ }^{21}$ In addition, Islam, by way of its authoritarian outlook, offered the leadership an opportune way to control and mobilise the masses.

The emphasis on Islam in the late 1970s was new in content and performed new functions: in line with the growing influence of radical Islam, it was strongly antiimperialist, anti-capitalist and anti-status quo. It was employed first of all to correct the criminal and lumpen image of NAP street militants in the eyes of the public by allowing these forces to adopt a more intense Islamic appearance. Furthermore, Islam was useful to discipline and control the party's hooligans. There is no doubt that the religious image the party adopted was the biggest cause of its success in the 1977 elections; it increased its vote twofold by drawing voters from the supporters of the pro-religious NSP. With the Islamic colour that the NAP's nationalism took, the rupture with Kemalist nationalism was complete, so much so that, as one leading spokesman of the NAP put it, '... Turkish nationalists are not Atatürkist, but Atatürk is a Turkish nationalist' ${ }^{22}$

The NAP's social base was too narrow for the party to expect to come to power through electoral politics. Thus, it hoped to accede to power through extraconstitutional routes, in a situation of political turmoil, public despair and 
widespread discrediting of parliamentary democracy. In addition to the NAP's 'Commandoes', 'Grey Wolves', and later 'Idealists', as they were termed at various stages, ${ }^{23}$ who attacked left-wing intellectuals and partisans, the late1970 s witnessed the rise of a new form of political terrorism, sectarian violence, provoked and manipulated by the party for the same goal. The Sunnite population was mobilised against the Alevis and Kurds on the grounds that the Alevis were irreligious communists. Sectarian violence spread from town to town, and in 1978 reached the level of a massacre of about one hundred Alevis in a south-east town. Worse still, Alevi-Sunni clashes spilled into squatter settlements around developed urban centres via the importation of kinship politics through internal migration. The official Kemalist ideology on national unity was once more violated, and the Turkish political system was brought to the brink of breakdown.

\section{Hyper-nationalism in post 1980 politics}

The NAP was suspended and later closed down and banned by the leaders of the 1980 coup. NAP leaders and some NAP militants were subjected to lengthy trials. In the immediate post-1980 period, the adherents of the party were physically and ideologically in disarray, resentful of the same harsh treatment they felt they were subjected to with the Turkish left.

The most durable successor to the NAP was formed in 1985 under the name of the Nationalist Labor Party (NLP), and in 1987, after the ban on ex-political leaders forming and leading new political parties was lifted by a referendum, the ex-leader of the NAP became the new leader of the NLP. However, most topcadre policy makers of the NAP had been coopted by the ruling liberalconservative party of the right, the Motherland Party (MP), a product of the structure and style of the new politics in Turkey. The MP, a broad coalition claiming to incorporate four main political traditions in Turkey-liberals to the left and right; hyper-nationalists, and the religious right-attracted NAP votes and even brought some ex-NAP cadres into government. The successor party of the NAP, therefore, had to be content with a much reduced power base.

More importantly, the NLP continued to suffer a fatal and historic split into a pan-Turkist and an Islam-centred Turkist wing, a process which had started in the late 1970s. The latter wing has been much more dynamic and assertive mainly due to its young and energetic policy making cadres since 1980. The rise of Islam as a defining component of Turkish national identity is due to the generally more-Islamised context of Turkish politics. All right-wing forces have been propelled toward clutching 'the rope of God', as it is put by most politicians on the right. Even the former leader of the social-democratic RPP, Bülent Ecevit, and the new party he formed in post-1980 period, the Democratic Left Party, have turned to courting the more politicised religious voters.

\section{PROSPECTS FOR HYPER-NATIONALISM AND RADICAL ISLAM IN THE 1990s}

As Turkey moves into the 1990s, two developments, one internal, the other external, have come to play a central role in the future course and discourse of 
radical Islam and Kemalist and hyper-nationalist nationalism. The internal development is the rise of the Kurdish question to the top of the Turkish political agenda. The external factor has been the collapse of the former Soviet Union and the after-effects of the 1991 Gulf War, the last obviously exacerbating the Kurdish problem.

\section{The Kurdish constraint}

The problem of Kurdish nationalism is a legacy of the past, especially of the strains of creating a 'state' before Turkish national consciousness had emerged. In its attempt to synchronise the formation of state and nation, Kemalist nationalism tried to suppress sociological forces like religion, social class, and ethnicity because of their divisive impact on national cohesion. The policy of the Kemalist state was shaped by one single concern: to preserve national unity and territorial integrity, and thus to guarantee the survival of the state. In time, however, because the task of nation-preserving became more difficult in the face of growing ideological and ethnic challenges, the manner in which the task was fulfilled also became more repressive. One unfortunate result of this was the refusal of the state to acknowledge officially a 'cultural' not political, Kurdish identity. If this had been done, say some 30 years ago, the present crisis might have been less political and more economic-cultural in substance.

What are the prospects for possible responses of Turkish nationalism of the official and the radical variants to Kurdish nationalist demands for cultural autonomy or independence? To begin with, there have, until recently, been two common modes of perceiving the problem and offering solutions. The tirst, the 'black' view, which has been adhered to by most state and right-wing political elites and by the bulk of the citizens, has denied even the Kurdish existence on Turkish territory, whereas the 'white' perspective, mostly of a minority marginal group, has unconditionally supported all Kurdish claims and complaints against the Turkish state.

Since the mid-1980s, however, proponents of a 'grey' shade have begun to push successfully for a Kurdish opening in the media and in the political arena, breaking most of the taboos ${ }^{24}$ surrounding the issue. For them, conceiving and practising politics in terms exclusively of preserving national unity have not produced a democratic outlook and conditions conducive for a pluralist democracy. Thus, in their view, it would be a delusion to base the future Kurdish policy of the state solely on a mechanistic interpretation of unitarism and on the conventional recipe of controlling and coopting. The prognosis that follows is that the primary emphasis must shift from 'preserving' to 'democratising-andpreserving' what Turkey has. The dominant conviction is that a democratic unitary state based on the codewords of conciliation, tolerance and genuine political pluralism, and organised around multi-ethnic, multi-lingual and multiideological groups can work in Turkey, although it may seem to be coming apart elsewhere.

To what extent has the Turkish radical nationalist camp and its party, the NLP, been sharing the 'grey' thinking which is emerging at all levels of society as a fresh alternative? The Turkist wing of the hyper-nationalist movement is reacting to Kurdish nationalism the way it reacted to Alevi-'communism' in the 1970s. The leader of the party can be heard referring to 'Kurds' and making pleas 
for a peaceful and democratic co-existence with them, while die-hard militants scattered around the heavily Turkish areas try to instigate violent Turkish reaction against Kurdish neighbours, friends, colleagues, and employees, and to block any 'grey' consideration of the Kurdish question.

Nevertheless, it is the influence of the dramatic changes in Turkish politics mainly brought about by an unprecedented 'opening up' to the outside world in the post-1980 era that produced the moderate genre, the 'grey'ists. There is no reason to think that the flow of the stream can be turned backwards.

\section{Global constraints and official nationalism}

The movement toward political democracy and economic liberalisation which these external developments promoted in most of the Third World also had an impact on Turkey's internal politics, in terms of an increasing priority on issues related to democracy, the rule of law, and human rights, especially since the October 1991 general elections. ${ }^{25}$ This 'external push' for democracy has been an increasing part of Turkish politics since the country applied for full membership in the European Community (EC) in 1987. Although the Community has not responded with enthusiasm, the idea of a prospective integration with Europe, even at an unknown future date, has been a source of strength for secular democratic values and trends in the country. The same cannot be said for the radical Islamist and hyper-nationalist forces whose commitment to the same values and practices is open to question.

Political developments in the Turkic-Muslim republics in the former Soviet Caucasus and Central Asia in turn have had a major impact on the nationalist and Islamist stances in Turkey. The current aspirations for democratisation and free market capitalism sweeping through that part of the world have reinforced the secular and modernising aspects of Kemalist ideology, both inside Turkey and in those republics. These new republics are in need of external support and guidance for transforming their systems which so far were insulated from any Western influence. There are two models they could emulate: either the secular and politically more open model of Turkey, or the fundamentalist framework of Iran. The dynamics of this transition period are full of signs that in this competition between the two countries over providing a prototype of development, Turkey has natural advantages based on its close historical and cultural ties with its Turkic cousins. Turkey's rising importance in the region is also a welcome development to its key ally, the U.S., which is trying to create a new balance of power in the former Soviet Union favorable to American interests, and is attempting to preclude any expansion and consolidation of Iranian influence in the region.

Turkey has embarked on a spate of diplomatic activity by exchanging visits of envoys, opening embassies, signing various economic and cultural agreements, and establishing satellite television broadcasts to the six Muslim republics. These moves toward the Turkic states have caused concern in some Western circles that the Ottoman Empire is resurrecting itself and that official Turkish nationalism has started to acquire an expansionist and aggressive character. This perspective misses the Turkish reality and misreads the changing direction and substance of Turkish foreign policy, which is characterised by pragmatic economic considerations in which irredentism, expansionism, and a desire for power are 
uncalled for. 'Ankara's new attitude toward ethnic Turkic groups in Azerbaijan and the former Soviet Central Asian republics is based on pragmatic foreign policy considerations rather than on ideological concerns. The Turks expect to gain major economic benefits from the development of closer ties with Uzbeks, Kazakhs, Kirghis, Turkmens, and Azerbaijanis' ${ }^{26}$ In short, Turkish efforts in the region aim at exploiting the economic possibilities of a massive market and at being a window and a link to the capitalist West, which is thought to be the best answer to the problems of economic liberalism.

The official Turkish stand has not moved away from its long-term commitment to staying within the Western bloc and pressing for entry into the EC. Ankara has not been facing a policy choice between being a member of the democratic community of the West and the Muslim-Turkic community of Central Asia, since it perceives them to be reconcilable options. In any event, since the Turkish application to the $\mathrm{EC}$ has been put aside pending resolution of the Eastern European membership question, it is not surprising that Europe's 'forgotten ally'27 has no choice but to move as fast as possible to reap the maximum economic benefits from relations with the Turkic republics and help its own painful economic transition process.

The immense political changes outside the country, especially in Central Asia, which radical nationalists have always claimed as Turkish ancestoral land, have inevitably had their greatest impact on hyper-nationalist forces and organisations in the 1990s. Similarly, the increasing intensity in the past several years of the Kurdish nationalist movement inside the country has also become a pivotal issue for the same forces and organisations to reposition and remobilise themselves.

The vision of a pan-Turkish Central Asia show an ideological obstinacy on the part of hyper-nationalist forces. These new states are totally unlikely to submit themselves to the shackles of a united pan-Turkist Empire, having already broken the shackles of dependence on another one. In other words, those nations have learnt the costs of compromising their sovereignty and sacrificing their individuality for a super-national political identity. Moreover, they are deeply aware of their national cultural values due to the former Soviet policy of divide and rule.

To put it differently, since the states there are coterminous with the nation, there is really less need for nationalism to be radical than it would be in fragmented societies with little sense of a common national consciousness. The difficulties encountered there are related to managing the process of transformation to the 'global' as opposed to a 'national' political culture of democracy, and to a viable model of capital accumulation and development integrated with the world economy. On all these counts, the hyper-nationalist cadres in Turkey have not renewed their rather arid and anachronistic political philosophy to incorporate new postures and strategies appealing to the new clientele. The authoritarian precepts of the NLP, for instance, are hardly likely to respond to the need to create the global political culture of democracy in Central Asia.

The transformation process in the Turkic republics has also had significant consequences for the fate of fundamentalist Islam at home. Having strengthened itself in the 1980s, the movement now is interested in 'Muslim' Central Asia as a potential site for an Islamist upsurge which will bolster the movement's morale 
and prestige and solidify its base at home. However, post-independence politics do not offer much optimism for Islam as being the source of legitimation for the emerging forms of state power.

To begin with, although Islamic identity as part of the culture is strong in these republics, the process of secularisation is well advanced. Given the predominantly secular outlook of the Muslim populace in these republics-a product of over 70 years of communist rule-and the widespread admiration for the modernising reforms of Kemal Atatürk, the chances for radical Islam to make headway in the republics seem to be very slim. On the contrary, it is Turkey's blending of Westernisation with secularism which provides an attractive model for these republics.

Consequently, any chance of success for Islamic fundamentalism in the region depends on the prospect of a growing antagonism between state and society in these republics. This in turn would reflect a political and economic performance-failure of the post-independence states. The other possibility of gaining any fundamentalist foothold in these societies lies in the evolution of politico-ethnic conflicts, like the one between Azerbaijan and Armenia over Karabagh, into a Muslim-Christian war. Under the impact of such uncertain conditions, radical Islam in Turkey has now entered into a phase of 'political quietism': taking stock, presenting a much more moderate face than in the previous decade, and consolidating its support. In short, fundamentalists are biding their time in the hope of a future opening produced not only by popular support in Turkey itself, but also by external ethno-political developments.

Bilkent University, Ankara

Ümit Cizre-Sakallioḡlu

\section{NOTES}

1. Throughout the article the prefixes 'hyper' and 'ultra' and the terms 'Turkist' and 'ethnic' will be used interchangeably to come before the word 'nationalism', to denote nationalism of a pan-Turkist type. Similarly, 'fundamentalism' and 'radical Islam' are the terms used throughout the article to refer to the Islamist ideology waging a struggle for political power on the basis of Islamic maxims.

2. G.Hossein Razi, 'Legitimacy, religion, and nationalism in the Middle East', American Political Science Review, 84, 1 (March 1990), p. 82.

3. Ibid.

4. There are two major Islamic sects in Turkey, the Sunni and the Alavi (Turkey's Shi'a). Turkish religious orders (tarikats) are Islamic organisations at the community level with the goal of searching for 'divine truth' through mysticism and rituals. The Alavi sect, an ardent supporter of secularism, has never supported religious orders. However, the Sunni sect, to which the majority of Turkey's Muslims belongs, has a multiplicity of orders.

5. Şerif Mardin, in his 'Religion and secularism in Turkey', in Ergun Özbudun and Ali Kazancigil (eds), Atatürk-the Founder of a Modern State (London: Hurst, 1981), p. 216 , stresses the paramount cultural character of this package.

6. Mardin, 'Religion and secularism in Turkey', pp. 213-217.

7. Şerif Mardin, 'Culture and religion: toward the year 2000', in Turkey in the Year 2000 (Ankara: Turkish Political Science Association Publication, 1989), pp. 169-170. 
8. Ibid., p. 171.

9. George S.Harris, 'Islam and the state in modern Turkey', Middle East Review, 11, 4 (Summer, 1979), p. 21.

10. Ilkay Sunar and Binnaz Toprak, 'Islam in politics: the case of Turkey', Government and Opposition, 18 (1983), p. 429.

11. Ergun Özbudun, 'Development of democratic government in Turkey: crises, interruptions and reequilibrations', in Ergun Özbudun (ed.), Perspectives on Democracy in Turkey (Ankara: Turkish Political Science Associaton Publication, 1988), p. 16.

12. Binnaz Toprak, 'Politicisation of Islam in a secular state: the National Salvation Party in Turkey', in Said Amir Arjomand (ed.), From Nationalism to Revolutionary Islam (Albany: State University of New York Press, 1984), pp. 127-129.

13. Bruce Lawrence, 'Muslim fundamentalist movements: reflections toward a new approach', in Barbara Freyer Stowasser (ed.), The Islamic Impulse (London: Croom Helm, 1988), p. 31.

14. Gencay Saylan, tslamiyet ve Sivaset (Ankara: V Yayınlan, 1987), p. 108.

15. Mardin, 'Culture and religion', pp. 179-180.

16. Udo Steinbach, 'Turkey's third republic'. Aussen Politik III, 1988, p. 245.

17. In this period, one institutional source producing the ideology of the ruling class was the Hearth of Intellectuals. The ideology they disseminated incorporated heavy doses of ethnic nationalism, Islam and all aspects of conservatism and was called 'the Turkish-Islamic Synthesis'. See Ilhan Tekeli, 'Türk-İslam Sentezi Üzerine' (On Turkish-Islamic Synthesis), Bilim ve Sanat, May, 1987, no. 77, pp.5-8. In addition, the secular Turkish business sector seems to have suggested the promotion of religion. One leading businessman, Vehbi Koç, in a letter he submitted to then-president Kenan Evren on 12 October, 1980, proposed that 'a nation with no religion is not possible. This time religious affairs should be regulated in such a way as not to allow the political parties to exploit it'. Evrenin Anıları Dizisi (The Memoirs of President Kenan Evren), Millivet (Istanbul daily), 23 December, 1990.

18. Mehmet Ali Aḡaogullari, 'The Ultranationalist right', in Irvin Schick and Ahmet Tonak (eds), Turkey in Transition (New York, Oxford: Oxford University Press, 1987), p. 185.

19. Alpaslan Türkeş (the leader of the party), $9 I_{\text {şı }}$ ve Türkiye (9 Lights and Turkey) (Ankara: 1979, unknown date of reprint), pp. 23-36.

20. Sadi Somuncuoḡlu, 'Milliyetçilik, Türkçülük, Ülkücülük' (Nationalism, Turkism and Idealism), Bozkurt (October 1972).

21. Interview with Alpaslan Türkes, Devlet (8 September, 1969).

22. Ayhan Tuḡcugil. Türk Milliyetçiliḡi Fikir Sistemi-Teori (The System of Thought of Turkish Nationalism-Theory) (Ankara: 1980), p. 121.

23. Jacob M. Landau, 'The Nationalist Action Party in Turkey', Journal of Contemporary History, 17 (1982), p. 594.

24. Ömer Karasapan, 'Democracy and the Kurds', MERIP (July-August 1988), p. 45.

25. Metin Heper, 'Consolidating Turkish democracy', Journal of Democracy, 3, 2 (April 1992), pp. 107, 114-116.

26. Sabri Sayari, 'Turkey: the changing European security environment and the Gulf Crisis', The Middle East Journal, 46, 1 (Winter 1992), p. 15.

27. I borrow the term from Dankwart A. Rustow's title of the book and employ it for Europe-Turkey: America's Forgotten Ally (New York: Council on Foreign Relations, 1987). 